\title{
Efficacy of a high potency 01 Manisa monovalent vaccine against heterologous challenge with foot-and-mouth disease virus of O/SEA/Mya-98 lineage in sheep
}

\author{
N.B. Singanallur ${ }^{a, 1}$, J.M. Pacheco ${ }^{b, 1}$, J. Arzt ${ }^{b}$, C. Stenfeldt ${ }^{b}$, G.T. Fosgate $^{c}$, L. Rodriguez ${ }^{b}$, \\ W. Vosloo ${ }^{\mathrm{a}, *}$ \\ ${ }^{a}$ Australian Animal Health Laboratory, CSIRO-Health and Biosecurity, Geelong, Australia \\ ${ }^{b}$ Plum Island Animal Disease Center, USDA-ARS, Orient Point, New York, USA \\ ${ }^{\mathrm{c}}$ Production Animal Studies, Faculty of Veterinary Science, University of Pretoria, Onderstepoort, South Africa
}

\begin{abstract}
* Corresponding author. CSIRO-Australian Animal Health Laboratory, Private Bag 24, Geelong, 3220, Victoria, Australia. E-mail address: wilna.vosloo@csiro.au (W. Vosloo).
\end{abstract}

\section{Highlights}

-A FMD vaccine was tested for efficacy against heterologous challenge in sheep using the coronary band challenge route.

-Different doses of vaccine were used to test the current practise of using half a cattle dose $(1 \mathrm{ml})$ in small ruminants.

-A full cattle dose $(2 \mathrm{ml}$ ) provided $50 \%$ protection $7 \mathrm{dpv}$, but half a dose provided no protection.

-At 14 days post vaccination, these doses provided improved protection, but not to all sheep.

-The $1 \mathrm{ml}$ dose should provide protection in sheep with high potency vaccine and challenge after more than 14 days.

\begin{abstract}
Potency tests for commercial oil-adjuvanted foot-and-mouth disease (FMD) vaccines are usually carried out in cattle, using a full dose $(2 \mathrm{ml})$ of vaccine and homologous virus challenge. However, in sheep the recommended vaccine dose is half of the cattle dose $(1 \mathrm{ml})$ and most vaccines have not been potency tested for this species, especially with heterologous viruses. To determine the efficacy of a high potency $\left(>6 \mathrm{PD}_{50}\right)$ FMD virus (FMDV) O1Manisa vaccine in sheep, we carried out a study using a heterologous FMDV (FMDV O/SKR/2010 - Mya-98 strain) challenge. Groups of seven animals each were vaccinated with $2 \times, 1 \times, 1 / 2 \times$ or $1 / 4 \times$ dose $(2 \mathrm{ml}, 1 \mathrm{ml}, 0.5 \mathrm{ml}$ or $0.25 \mathrm{ml}$ respectively) and challenged at 7 days post vaccination (dpv). Only 3 of the 7 sheep in the group vaccinated with $2 \mathrm{ml}$ were protected. With 2 additional groups, receiving double or single doses and challenged at 14 $d p v, 4$ of 7 sheep were protected in each group. None of the sheep had measurable
\end{abstract}


neutralising antibodies against the vaccine or challenge virus at $7 \mathrm{dpv}$. However, all vaccinated animals challenged at $14 \mathrm{dpv}$ had a homologous neutralising response against FMDV 01 Manisa on the day of challenge and all but one animal also had a heterologous response to FMDV O/SKR/2010. Infectious FMDV and viral RNA could be found in nasal swabs between 1 and 6 days post challenge (dpc) in most vaccinated sheep, but those vaccinated with higher doses or challenged at $14 \mathrm{dpv}$ showed significant decreases in the level of FMDV detection. Intermittent virus shedding was noticed between 1 and $35 \mathrm{dpc}$ in all vaccinated groups, but persistent infection could be demonstrated only in 4 sheep (20\%). This study showed that at the recommended dose, a high potency ( $>6 \mathrm{PD}_{50}$ ) FMDV O1Manisa vaccine does not protect sheep against a heterologous challenge at $7 \mathrm{dpv}$. However, partial protection was observed when a double dose was used at $7 \mathrm{dpv}$ or when double or single dose vaccinated sheep were challenged at $14 \mathrm{dpv}$.

\section{Keywords}

Foot and mouth disease virus

Vaccine efficacy

Dose response

Heterologous challenge

Sheep

\section{Introduction}

The 2001 foot-and-mouth disease (FMD) outbreak in the United Kingdom (UK) resulted in depopulation of almost 6.5 million animals under the European Union's 'culling and stamping out' policy (Haydon et al., 2004) which together with other costs led to losses estimated at US\$6.9 billion. In the same year, an FMD outbreak in Uruguay was managed using vaccination to assist the eradication campaign at a cost of US\$200 million (Sutmoller and Olascoaga, 2002). Public outcry against the unnecessary destruction of animals and other factors have led to a change in control options in various parts of the world (AUSVETPLAN, EU Council Directive, 2003) and have placed more emphasis on emergency vaccine banks for areas where the disease is not present.

Sheep and goats comprise the majority of the world's FMD-susceptible livestock ( 2 billion head) and occupy an important position in agriculture-based economies throughout the world (FAO Statistical Year Book, 2013). Clinical FMD often goes undetected in these species, leading to disease dissemination before an outbreak is diagnosed. The early stages of the 2001 FMD epidemic in the UK was attributed to the virus transmitted on a large scale by sheep (Ferguson et al., 2001; Gibbens and Wilesmith, 2002). It is therefore important to test the efficacy of FMD vaccines in sheep, as they may be target species for endemic disease control as well as for countermeasures applied during outbreaks in previously free regions.

Studies have shown that sheep are protected against homologous airborne challenge when vaccinated with three-fold or six-fold doses of a conventional monovalent vaccine (Gibson et al., 1984). High potency vaccine formulations with increased payloads of FMDV antigen resulted in early protection in cattle (4 days post vaccination $-\mathrm{dpv}$ ), but were less effective 
in pigs (Doel et al., 1994). Early protection in sheep vaccinated with high potency vaccines against challenge with airborne virus within 4 days of vaccination was subsequently studied (Cox et al., 1999). Further studies with high potency vaccines showed a reduction or cessation in virus replication in the oropharynx in sheep compared to those that received low potency (3-6 $\mathrm{PD}_{50}$ ) conventional vaccines (Cox et al., 2003).

Vaccine potency tests are usually carried out using homologous virus challenge; so there is a dearth of knowledge on the performance of a vaccine against a heterologous virus that is antigenically different from the vaccine strain. Parida et al. (2008) first demonstrated early protection using high potency vaccination with heterologous virus challenge in sheep. Recent studies have shown variability in cross protection with high potency vaccines against heterologous challenge in cattle (Brehm et al., 2008; Singanallur et al., 2011).

The recommended doses for oil-adjuvanted vaccines (ISA 206) are $2 \mathrm{ml}$ for large ruminants and half a dose for small ruminants (Doel, 2003). Since most of the emergency vaccines are high potency formulations $\left(>6 P D_{50}\right.$ ), it is possible that lower doses of vaccine could provide protection, given that the antigenic differences between the vaccine and challenge virus are not too pronounced, impacting on the number of animals that could be vaccinated during an emergency when doses are limited.

Recently the Mya-98 lineage of serotype O SEA genotype has caused outbreaks in regions previously free of FMD (Valdazo-Gonzalez et al., 2013; Nishiura and Omori, 2010). Data on the performance of high potency vaccines in sheep against this lineage of virus are not available. In the present study, the efficacy of different doses of a high potency O1 Manisa vaccine $\left(>6 P D_{50}\right)$ was assessed against challenge with the O-Mya-98 lineage virus.

\section{Materials and methods}

\subsection{Challenge virus and cells used in the study}

Foot-and-mouth disease virus (FMDV) O/SKR/2010 (Mya-98 strain) was obtained from cattle during an outbreak in South Korea (Yoon et al., 2013). This isolate was amplified as previously described (Pacheco et al., 2016) and titrated in bovine tongue epithelium (10.5 $\left.\mathrm{BTID}_{50} / \mathrm{ml}\right)$.

LFBK- $\alpha_{v} \beta_{6}$ cells (LaRocco et al., 2013) were propagated in Dulbecco's modified Eagle medium (DMEM; Cat. No. 11965092; Gibco) supplemented with 10\% foetal bovine serum (Cat. No. SH30071.03; HyClone) and antibiotics (Cat. No. 15240062; Gibco).

\subsection{Experimental animals and vaccine}

All the protocols for experimentation with live sheep were approved (AEC 1636 and IACUC 231-11-R). Cross-bred Dorset sheep, 6-12 months age ( 40 kg), were kept at the BSL3 animal facility at the Plum Island Animal Diseases Centre (PIADC) in quarantine for 5-8 days before the commencement of the experiment. 
A high potency monovalent $\mathrm{O} 1$ Manisa double oil adjuvant vaccine ( $>6 \mathrm{PD}_{50}$ in $2 \mathrm{ml}$, bovine dose) was prepared from the Australian FMD vaccine reserve by Merial Company Limited, United Kingdom.

\subsection{Vaccine efficacy studies, challenge and sampling protocol}

Experiments were performed in two phases (Table 1). For each phase, all animals were housed in the same room of $27 \mathrm{~m}^{2}$. Four groups of seven sheep each (Groups 1-4) were vaccinated with vaccine volumes as in Table 1 (the recommended dose for small ruminants is $1 \mathrm{ml}$, therefore $2 \times$ refers to $2 \mathrm{ml}, 1 \times$ to $1 \mathrm{ml}, 1 / 2 \times$ to $0.5 \mathrm{ml}$ and $1 / 4 \times$ to $0.25 \mathrm{ml}$ of vaccine) and challenged on $7 \mathrm{dpv}$ (phase 1). Two more groups of seven sheep each (Groups 5 and 6 ) were vaccinated with $1 \times$ and $2 \times$ vaccine dose (Table 1 ) and challenged on $14 \mathrm{dpv}$ (phase 2 ). Vaccine was administered intramuscularly in the mid-neck region.

The sheep were challenged by intradermal inoculation in the coronary band (CB) with $10^{6}$ $\mathrm{BTID}_{50}(400 \mu \mathrm{l})$ of O/SKR/2010. Animals were sedated with xylazine hydrochloride ( $2 \%$ Xylazine at $0.67 \mathrm{ml} / 100 \mathrm{~kg}$ b.wt) and the reversal was tolazoline $(2 \mathrm{mg} / \mathrm{kg}$ b.wt).

Vaccination was staggered so that challenge by CB occurred on the same day for all animals in each phase. Since the experiment was carried out in two phases, each phase had 4 unvaccinated control sheep (Group $7 ; n=8$ ) that were challenged along with the vaccinated groups.

Sheep were monitored once per day (temperature, swabs and bleeding) and detailed clinical examination performed every second day (until 6 days post challenge (dpc) for phase 1 and $10 \mathrm{dpc}$ for phase 2) for the progression of FMD-specific clinical signs which were recorded using a scoring system described previously (Stenfeldt et al., 2015; Pacheco and Mason, 2010). The highest score possible following CB inoculation was 16 . Rectal temperatures were measured daily for the duration of each phase and temperatures $\geq 40{ }^{\circ} \mathrm{C}$ scored as fever.

The frequency of collection for all clinical samples is provided in Table 1. Clotted blood for serology and detection of FMDV RNA was collected daily between 0 to $6 \mathrm{dpc}$ and 0 to $10 \mathrm{dpc}$ for phases and 1 and 2 respectively and weekly subsequent to this (phase 2). Nasal swabs were collected daily from 0 to $6 \mathrm{dpc}$ for phase 1 and daily from 0 to $10 \mathrm{dpc}$, followed by twice weekly sampling for phase 2 . One cotton tip was introduced in each nostril and both placed into a tube containing $1 \mathrm{ml}$ of MEM with $25 \mathrm{mM}$ HEPES. Oro-pharyngeal fluids were collected twice a week starting at $14 \mathrm{dpc}$ from animals in phase 2 only, using probang cups designed for sheep and placed into tubes with $2 \mathrm{ml}$ of MEM with $25 \mathrm{mM}$ HEPES. All samples were stored at $-70^{\circ} \mathrm{C}$ until further processing. 
Table 1. Experimental design and challenge results.

\begin{tabular}{|c|c|c|c|c|c|c|c|c|c|c|}
\hline Phase $^{a}$ & ${ }^{a}$ Group & $\begin{array}{c}\text { Vaccine } \\
\text { dose }^{b}\end{array}$ & $\begin{array}{l}\text { Day of } \\
\text { challenge } \\
\text { (dpv) }^{c}\end{array}$ & $\begin{array}{c}\text { No of } \\
\text { animals }\end{array}$ & $\begin{array}{l}\text { Serum } \\
\text { collected } \\
\text { at }(\mathrm{dpc})^{\mathrm{d}}\end{array}$ & $\begin{array}{l}\text { Nasal } \\
\text { swabs } \\
\text { collected } \\
\text { at (dpc) }\end{array}$ & $\begin{array}{l}\text { Probangs } \\
\text { collected } \\
\text { at (dpc) }\end{array}$ & Protected & $\begin{array}{l}\text { Onset } \\
\text { of } \\
\text { disease } \\
\text { (dpc) }\end{array}$ & $\begin{array}{c}\text { Mean } \\
\text { clinical } \\
\text { score } \\
\text { (excluding } \\
\text { protected } \\
\text { animals) }\end{array}$ \\
\hline 1 & 1 & $\begin{array}{l}0.25 \mathrm{ml} \\
(1 / 4 \times)\end{array}$ & 7 & 5 & $-7,0-6$ & $0-6$ & $\begin{array}{l}\text { Not } \\
\text { collected }\end{array}$ & 0 & $2-4$ & 8.6 \\
\hline 1 & 2 & $\begin{array}{l}0.5 \mathrm{ml} \\
(1 / 2 \times)\end{array}$ & 7 & 7 & $-7,0-6$ & $0-6$ & $\begin{array}{l}\text { Not } \\
\text { collected }\end{array}$ & 1 & $2-4$ & 9.2 \\
\hline 1 & 3 & $\begin{array}{l}1 \mathrm{ml} \\
(1 \times)\end{array}$ & 7 & 6 & $-7,0-6$ & $0-6$ & $\begin{array}{l}\text { Not } \\
\text { collected }\end{array}$ & 0 & $2-4$ & 8.3 \\
\hline 2 & 4 & $\begin{array}{l}2 \mathrm{ml} \\
(2 \times)\end{array}$ & 7 & 7 & $\begin{array}{l}-7,0-10 \\
14,21 \\
28,35\end{array}$ & $\begin{array}{l}0-10,14 \\
17,21,24 \\
28,31,35\end{array}$ & $\begin{array}{l}14,17,21 \\
24,28,31 \\
35\end{array}$ & 3 & $4-6$ & 4.2 \\
\hline 2 & 5 & $\begin{array}{l}1 \mathrm{ml} \\
(1 \mathrm{x})\end{array}$ & 14 & 7 & $\begin{array}{l}-14,-7 \\
0-10,14 \\
21,28,35\end{array}$ & $\begin{array}{l}0-10,14 \\
17,21,24 \\
28,31,35\end{array}$ & $\begin{array}{l}14,17,21 \\
24,28,31 \\
35\end{array}$ & 4 & $4-6$ & 3.7 \\
\hline 2 & 6 & $\begin{array}{l}2 \mathrm{ml} \\
(2 x)\end{array}$ & 14 & 7 & $\begin{array}{l}-14,-7 \\
0-10,14 \\
21,28,35\end{array}$ & $\begin{array}{l}0-10,14 \\
17,21,24 \\
28,31,35\end{array}$ & $\begin{array}{l}14,17,21 \\
24,28,31 \\
35\end{array}$ & 4 & $4-6$ & 3.7 \\
\hline $\begin{array}{l}1 \text { and } \\
2\end{array}$ & 7 & Naïve & - & 8 & $\begin{array}{l}\text { Phase 1: } \\
0-6 \\
\text { Phase 2: } \\
0-10,14 \\
21,28,35\end{array}$ & $\begin{array}{l}\text { Phase 1: } \\
0-6 \\
\text { Phase 2: } \\
0-10,14 \\
17,21,24 \\
28,31,35\end{array}$ & $\begin{array}{l}\text { Phase 1: } \\
\text { not } \\
\text { collected } \\
\text { Phase 2: } \\
\text { 14, 17, 21, } \\
24,28,31 \text {, } \\
35\end{array}$ & 0 & 2 & 11.7 \\
\hline
\end{tabular}

${ }^{a}$ Experiments were performed in two phases, with 25 sheep in each, with 4 unvaccinated controls (naïve) per phase (group 7).

${ }^{b}$ The vaccine preparation used was the same for all the experiments. Different volumes of the same concentration vaccine were used to adjust doses. Animals were vaccinated by the intramuscular route at one site in the neck.

${ }^{\mathrm{c}}$ Related to day of vaccination (days post vaccination $=\mathrm{dpv}$ ).

${ }^{d}$ Related to day post challenge (day post challenge $=d p c$ ).

\subsection{Serological assays to detect neutralising antibodies}

Sera collected at the time of vaccination, challenge and at $6 \mathrm{dpc}$ were heat-inactivated at $56{ }^{\circ} \mathrm{C}$ for $30 \mathrm{~min}$ before testing. Virus neutralization assays were performed with 01 Manisa and O/SKR/2010 respectively, following standard procedures (Golding et al., 1976). The $\log _{10}$ serum antibody titres were expressed as the final dilution of serum where $50 \%$ of wells showed cytopathic effect (Kärber, 1931). Titre values of $\geq 1.2 \log _{10}$ were taken as a serological response (OIE Terrestrial Manual, 2012).

\subsection{Detection of antibodies to the non-structural proteins of FMDV}

Sera collected at the time of vaccination, challenge and at euthanasia were tested for the presence of antibodies against FMDV non-structural proteins (NSP) by utilizing the PrioCHECK ${ }^{\oplus}$ FMDV NS (Prionics, Lelystad, Netherlands). 


\subsection{Quantitation of viral RNA in samples}

Real-time semi-quantitative reverse transcriptase PCR (RT-qPCR) for detection of viral RNA in serum, nasal swabs and probang samples was carried out targeting the 3D polymerase region of the FMDV genome with primers adapted from Rasmussen et al. (2003) and the AgPATH-ID One-step RT-PCR kit (Applied Biosystems, Carlsbad, CA, USA), according to Stenfeldt et al., 2016b. Samples with a $\mathrm{Ct}<40$ were considered positive. Cycle threshold values were converted into FMDV genome copy numbers per millilitre as previously described (Arzt et al., 2010).

\subsection{Virus isolation from probangs}

Probang samples were processed with triclorotrifluoroethane before inoculation of cells to isolate FMDV (Pacheco et al., 2015). One cell amplification cycle was performed in $25 \mathrm{~cm}^{2}$ flasks and read for cytopathic effect at $72 \mathrm{~h}$. Results were confirmed by RT-qPCR.

\subsection{Statistical analysis}

The normality assumption was assessed by calculating descriptive statistics, plotting histograms, and performing the Anderson-Darling test for normality using MINITAB Statistical Software, Release 13.32 (Minitab Inc, USA). Data were transformed using the base-10 logarithm $\left(\log _{10}\right)$ or by ranking when necessary to improve the distributional form prior to performing parametric regression analyses. Rectal temperatures were descriptively presented as mean and standard deviation while other quantitative data were presented as the median and range. Rectal temperatures measured at each dpc were compared among treatment groups using 1-way ANOVA with Bonferroni correction of $\mathrm{P}$ values for multiple post-hoc tests. All other quantitative data were compared at each dpc using Kruskal-Wallis tests with multiple post-hoc tests adjusted using Bonferroni correction. Correlation between quantitative variables was estimated using Spearman's rho. Comparison of the analytical sensitivity of virus isolation and RT-PCR on probang samples was performed using McNemar's chi-square test. Linear mixed models were used to estimate the effect of treatment group on the quantitative outcomes of rectal temperature and viral titres estimated from quantitative PCR. Independent models were fit for each outcome in addition to a combined model for two PCR specimens (serum and nasal swabs). All models included a random effect term for animal with a first-order autoregressive correlation structure to account for the repeated measurements. Fixed effects included terms for treatment group, experimental phase ( 1 versus 2 ), and dpc. Bonferroni correction was used to adjust $P$ values for multiple post-hoc comparisons. Statistical analyses were performed in commercially available software (IBM SPSS Statistics Version 23, International Business Machines Corp., Armonk, New York, USA) and significance set as $\mathrm{P}<0.05$.

\section{Results}

\subsection{Clinical signs detected during the vaccine efficacy trials}

Two sheep in group 1 and one in group 3 died due to complications during the virus challenge procedure. Animals vaccinated with $1 / 4 \times, 1 / 2 \times$ or $1 \times$ vaccine dose and 
unvaccinated control animals challenged at $7 \mathrm{dpv}$ were not protected. Lesions were observed starting at $2 \mathrm{dpc}$ and mean clinical scores ranged from 8.3 to 9.2 at $6 \mathrm{dpc}$. Three animals in the group receiving a double vaccine dose and challenged at $7 \mathrm{dpv}$ were protected with the remaining unprotected animals showing lower mean clinical scores (4.2) (Table 1; Supplementary table 1). In the groups receiving $1 \times$ or $2 \times$ dose of vaccine and challenged at $14 \mathrm{dpv}$ four of the 7 animals were protected from clinical lesions. In these groups appearance of clinical lesions was delayed to $4 \mathrm{dpc}$ and mean clinical scores were 3.7 in each group at $6 \mathrm{dpc}$ (Table 1; Supplementary table 2).

All animals had fever for at least one day between 1 and $6 \mathrm{dpc}$, except for two animals (\#32 and \#67) (results not shown). However, these two animals developed clinical signs (i.e., vesicles at sites distant from inoculation point; Fig. 1).

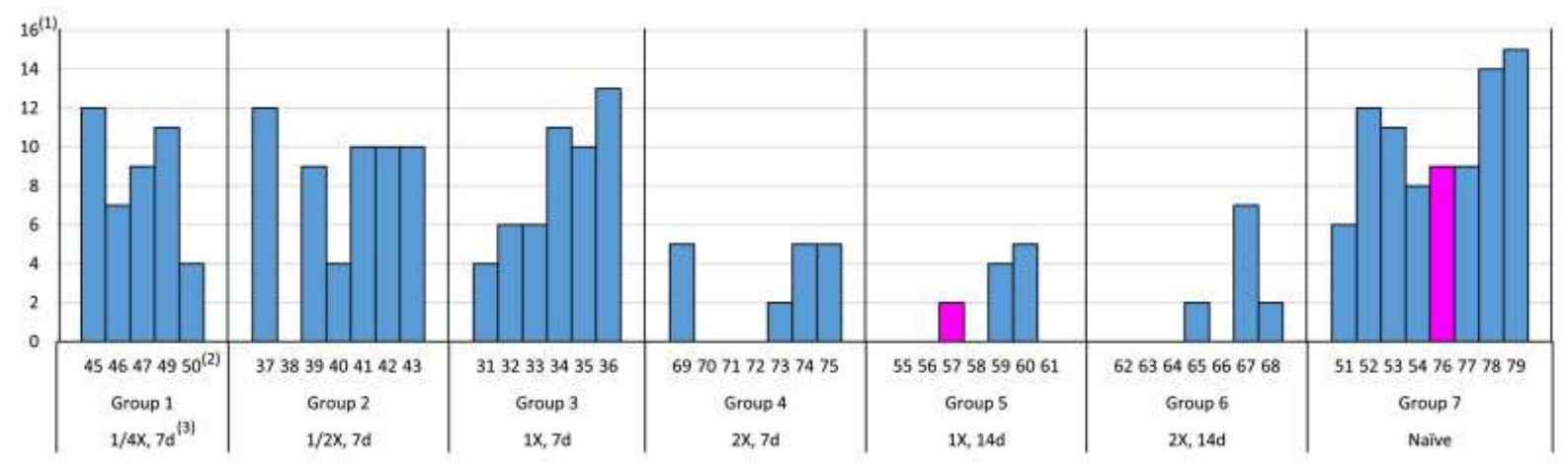

Fig. 1. Clinical scores at 6 days post inoculation, the final observation day for groups 1, 2, 3 and animals $\mathbf{5 1}$, 52, 53 and 54. All other animals survived to 35 days post inoculation, but scores remained unchanged, except for animals highlighted in pink; ET\#57 and 76 clinical scores progressed from 2 to 4 and 9 to 10 respectively by 8 days post challenge. Vesicular lesions observed at medial or lateral aspects of the two main digits of each foot contributed one point towards a cumulative score, with additional single points counted for lesions on the dental pad, tongue, lips and nostrils. The highest score possible following coronary band inoculation was 16 as lesions on the foot used for inoculation were not counted. (1) Clinical Scores; (2) Ear Tag Numbers (ET); (3) d = day post vaccination.

\subsection{Detection of FMDV RNA in the blood and nasal swabs}

FMDV RNA was detected in serum of all non-vaccinated animals (group 7) for at least one day from 1 to $6 \mathrm{dpc}$ with the majority (6/8) positive at $3 \mathrm{dpc}$ (Fig. 2). For vaccinated animals, FMDV RNA was detected intermittently in serum of a number of the animals 1 to $4 \mathrm{dpc}$.

Only one animal each had viral RNA at $6 \mathrm{dpc}$ in groups 3 and 6 respectively. In groups 1-3, viral RNA was more often detected, and at higher levels, compared to the groups that had received higher vaccine doses and/or had been challenged at longer periods post vaccination (groups 4-6). However, animals with no FMDV RNA detected in serum were not necessarily those that were clinically protected, or vice versa. Overall, there was variability in the amount of FMDV RNA detected in serum among groups $(P<0.001$; Supplementary table 3 ) and sheep in groups 4-6 had significantly less RNA and for shorter periods of time compared to the unvaccinated controls $(P<0.05)$. 

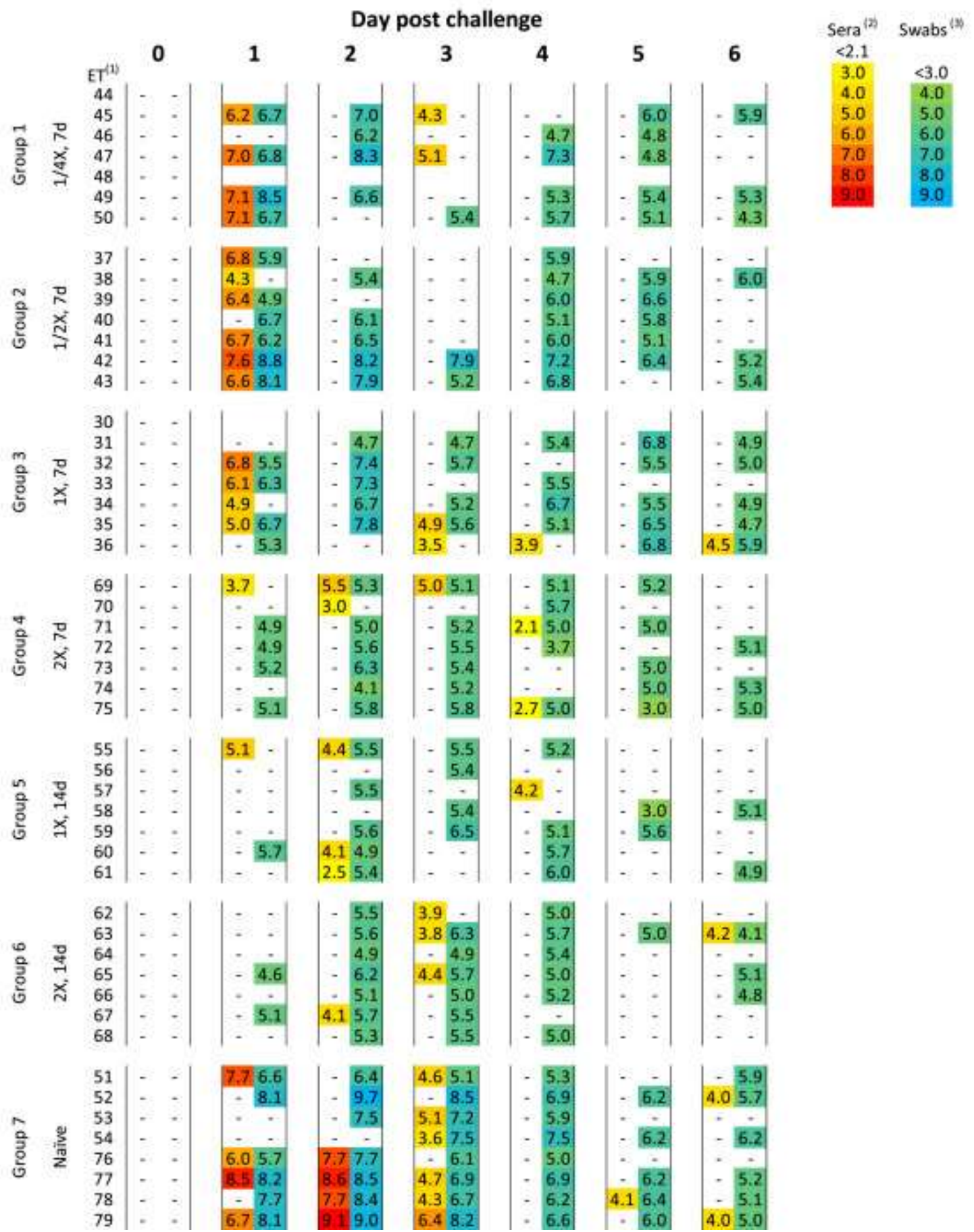

Fig. 2. RNA detected in sera and swabs from 0 to 6 days post challenge ( $\log _{10}$ RNA copy number per $\mathrm{ml}$ of FMDV O/SKR/2010). Animals are arranged by treatment group, as previously described. Doses of vaccine ranged from $1 / 4 \mathrm{X}$ to $2 \mathrm{X}$. Animals were challenged at 7 or 14 days post vaccination (d); (1) ET: Ear Tag number; (2) Color coding indicates stratified quantity of FMDV RNA detected in sera; (3) Color coding indicates stratified quantity of FMDV RNA detected in nasal swabs. "-" Indicates below limit of detection, $\log _{10} 2.1$ copies per ml for sera and $\log 103.0$ copies per ml for nasal swabs.

FMDV RNA was detected in nasal swabs from $1 \mathrm{dpc}$, with most swabs positive by $2 \mathrm{dpc}$ (Fig. 2). In groups 4-6 the frequency of detection decreased after $6 \mathrm{dpc}$, but intermittent shedding continued until 31 dpc (Figs. 2 and 3). FMDV RNA was found in swabs at least twice in all sheep, including those that were clinically protected. In groups 4-6 fewer 
animals had detectable RNA in their swabs by $1 \mathrm{dpc}$, compared to groups $1-3$. Highest levels of FMDV RNA were obtained in group 7 followed by the phase 1 group, with the least detection in phase 2 groups (Supplementary table 4). Overall, there was variability in the amount of FMDV RNA detected in swabs among groups when summarized for the entire trial $(P=0.001$; Supplementary table 4$)$ and sheep in groups $4-6$ had significantly less RNA compared to the unvaccinated controls $(P<0.05)$.

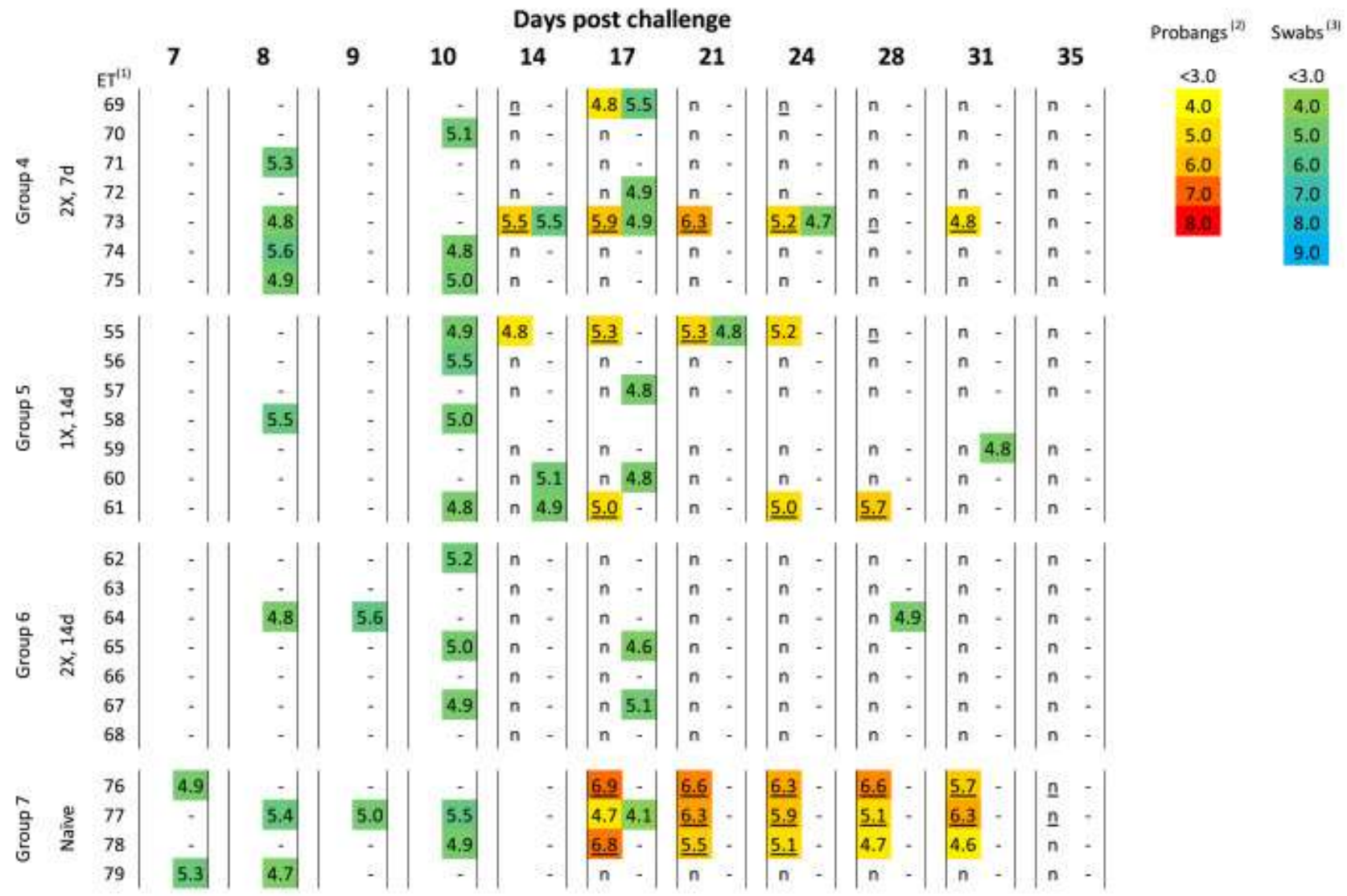

Fig. 3. RNA detected in probangs and swabs collected daily (7 to $10 \mathrm{dpc}$ ) or twice per week (14 to $35 \mathrm{dpc}$ ). Results are expressed in $\log _{10}$ RNA copy number per $\mathrm{ml}$ of FMDV O/SKR/2010. Animals not included in this figure were humanely euthanized at $6 \mathrm{dpc}$. Animals are arranged by treatment group, as previously described. Doses of vaccine ranged from $1 X$ to $2 X$. Animals were challenged at 7 or 14 days post vaccination (d). (1) ET: Ear Tag number; (2) Color coding indicates stratified quantity of FMDV RNA detected in probangs. Underlined number indicates virus isolation positive sample. Non-underlined value indicates virus isolation negative sample. " $n$ " indicates below limit of detection, $\log _{10} 3.0$ copies; (3) Color coding indicates stratified quantity of FMDV RNA detected in nasal swabs. "-" indicates below limit of detection, $\log _{10} 3.0$ copies per ml. Color scale is kept from 4.0 to 9.0 to help comparison with nasal swab results in Fig. 2.

\subsection{FMDV RNA and virus isolation from probangs}

Probangs were collected twice a week after $14 \mathrm{dpc}$ from sheep in phase 2. Both viral RNA and live virus were found in three of the four control sheep in Group 7 between 14 and 31 $\mathrm{dpc}$. Infectious virus was isolated from two of these sheep at $35 \mathrm{dpc}$, but viral RNA was not detected. One sheep (\#79) remained negative for the duration of sampling. In group 6 the probangs were negative in all animals (Fig. 3). Overall, there were significant differences in FMDV RNA levels in probangs between the experimental groups and the unvaccinated 
controls $(P=0.002$; Supplementary table 5$)$ but there were no differences among the different experimental groups themselves $(P>0.05)$. The sensitivity of FMDV detection via virus isolation and RT-qPCR on probang specimens was not statistically different $(P=0.226)$. Only two sheep out of 21 vaccinated in phase 2 studies (Groups 4-6) had viral RNA after 28 dpc.

\subsection{Serological responses measured during the trial}

Sera from all sheep were tested for the presence of neutralising antibodies at $0 \mathrm{dpv}, 0 \mathrm{dpc}$ and $6 \mathrm{dpc}$, against vaccine (O1 Manisa) and challenge (O/SKR/2010) viruses. No sheep had measurable neutralising antibodies when tested with either strain, at 0 and $7 \mathrm{dpv}$, but all 14 animals challenged at $14 \mathrm{dpv}$ had homologous response against 01 Manisa at the time of challenge. Also, in these two groups, all but one had heterologous response to $\mathrm{O} / \mathrm{SKR} / 2010$ at $0 \mathrm{dpc}(\mathrm{P}<0.001$; Table 2; Supplementary table 6$)$. Six days after challenge, all animals in all groups (including non-vaccinated controls) were sero-positive for both strains. The titres among groups were significantly different $(P<0.001$; Supplementary table 6$)$. Interestingly, 9 of the 12 protected animals did not have detectable antibodies at the time of challenge, therefore there was no correlation between protection and neutralising antibody levels.

Table 2. Serum neutralization titres for sheep in different vaccine groups pre- and post-challenge.

\begin{tabular}{|c|c|c|c|c|c|c|c|c|}
\hline \multirow{2}{*}{ Groups } & \multirow{2}{*}{$\mathrm{ET}^{\mathrm{a}}$} & \multicolumn{4}{|c|}{01 Manisa } & \multicolumn{3}{|c|}{ O/SKR/2010 } \\
\hline & & $-14 d p c^{b}$ & $-7 \mathrm{dpc}$ & $0 \mathrm{dpc}$ & $6 \mathrm{dpc}$ & $-14 d p c-7$ & $=0 \mathrm{dpc}$ & $6 \mathrm{dpc}$ \\
\hline & 44 & & - & - & & - & - & \\
\hline & 45 & & - & - & 2.10 & - & - & 2.40 \\
\hline & 46 & & - & - & 2.10 & - & - & 2.40 \\
\hline & 47 & & - & - & 2.40 & - & - & 2.40 \\
\hline Group 1 & & & - & - & & - & - & \\
\hline & 49 & & - & - & 1.80 & - & - & 2.40 \\
\hline & 50 & & - & - & 2.40 & - & - & 2.40 \\
\hline & Mean & & - & - & $2.17 / 2.1$ & - & - & $2.41 / 2.4$ \\
\hline & SE & & - & - & 0.11 & - & - & 0.00 \\
\hline & 37 & & - & - & 2.40 & - & - & 2.40 \\
\hline & 38 & & - & - & 2.40 & - & - & 2.10 \\
\hline & 39 & & - & - & 2.10 & - & - & 2.40 \\
\hline & 40 & & - & - & 2.40 & - & - & 2.40 \\
\hline Group 2 & 41 & & - & - & 2.70 & - & - & 2.40 \\
\hline & 42 & & - & - & 1.80 & - & - & 2.10 \\
\hline & 43 & & - & - & 2.10 & - & - & 2.40 \\
\hline & Mean & & - & - & $2.28 / 2.4$ & - & - & $2.32 / 2.4$ \\
\hline & SE & & - & - & 0.11 & - & - & 0.06 \\
\hline & 30 & & - & - & & - & - & \\
\hline Group 3 & 31 & & - & - & 2.10 & - & - & 2.40 \\
\hline & 32 & & - & - & 2.10 & - & - & 2.40 \\
\hline & 33 & & - & - & 2.10 & - & - & 2.40 \\
\hline
\end{tabular}




\begin{tabular}{|c|c|c|c|c|c|c|c|c|c|}
\hline \multirow{2}{*}{ Groups } & \multirow{2}{*}{$\mathrm{ET}^{\mathrm{a}}$} & \multicolumn{4}{|c|}{ O1 Manisa } & \multicolumn{4}{|c|}{ O/SKR/2010 } \\
\hline & & $-14 d p c^{\prime}$ & $-7 d p c$ & $0 \mathrm{dpc}$ & $6 \mathrm{dpc}$ & $-14 d p c$ & $=-7 \mathrm{dpc}$ & $=0 \mathrm{dpc}$ & $6 \mathrm{dpc}$ \\
\hline & 34 & & - & - & 2.40 & & - & - & 2.40 \\
\hline & 35 & & - & - & 2.40 & & - & - & 1.80 \\
\hline & 36 & & - & - & - & & - & - & 1.20 \\
\hline & Mean & & - & - & $1.96 / 2.1$ & & - & - & $2.11 / 2.4$ \\
\hline & SE & & - & - & 0.28 & & - & - & 0.20 \\
\hline & 69 & & - & - & 3.00 & & - & 1.20 & 3.30 \\
\hline & 70 & & - & - & 2.40 & & - & - & 3.30 \\
\hline & 71 & & - & - & 3.00 & & - & 1.20 & 3.30 \\
\hline & 72 & & - & - & 3.30 & & - & - & 3.00 \\
\hline Group 4 & 73 & & - & 1.20 & 3.00 & & - & 1.20 & 3.30 \\
\hline & 74 & & - & - & 2.70 & & - & - & 3.30 \\
\hline & 75 & & - & - & 2.40 & & - & - & 3.30 \\
\hline & Mean & & - & - & $2.84 / 3.0$ & & - & - & $3.27 / 3.3$ \\
\hline & SE & & - & - & 0.13 & & - & - & 0.04 \\
\hline & 55 & - & - & 1.20 & 3.00 & - & - & 1.20 & 3.00 \\
\hline & 56 & - & - & 1.20 & 2.40 & - & - & 1.20 & 2.40 \\
\hline & 57 & - & - & 1.50 & 2.70 & - & - & 1.20 & 2.70 \\
\hline & 58 & - & - & 1.80 & 3.00 & - & - & 1.80 & 2.70 \\
\hline Group 5 & 59 & - & - & 1.20 & 3.00 & - & - & 1.20 & 2.70 \\
\hline & 60 & - & - & 1.20 & 2.70 & - & - & - & 2.40 \\
\hline & 61 & - & - & 1.20 & 2.70 & - & - & 1.50 & 2.40 \\
\hline & Mean & $1-$ & - & 1.34 & $2.80 / 2.7$ & - & - & 1.25 & $2.62 / 2.7$ \\
\hline & SE & - & - & 0.09 & 0.09 & - & - & 0.14 & 0.09 \\
\hline & 62 & - & - & 1.20 & 2.40 & - & - & 1.50 & 2.70 \\
\hline & 63 & - & - & 1.50 & 3.30 & - & - & 2.10 & 3.60 \\
\hline & 64 & - & - & 1.80 & 3.00 & - & - & 2.10 & 3.00 \\
\hline & 65 & - & - & - & 2.10 & - & - & 1.20 & 2.40 \\
\hline Group 6 & 66 & - & - & 1.20 & 3.00 & - & - & 1.50 & 3.30 \\
\hline & 67 & - & - & 1.80 & 2.40 & - & - & 1.20 & 2.70 \\
\hline & 68 & - & - & 1.80 & 3.00 & - & - & 1.80 & 3.60 \\
\hline & Mean & $1-$ & - & 1.47 & $2.75 / 3.0$ & - & - & 1.63 & $3.04 / 3.0$ \\
\hline & SE & 0 & 0.00 & 0.14 & 0.17 & 0.00 & 0.00 & 0.14 & 0.18 \\
\hline & 51 & & & - & 2.60 & & & - & 2.40 \\
\hline & 52 & & & - & 2.60 & & & - & 2.40 \\
\hline & 53 & & & - & 2.40 & & & - & 2.40 \\
\hline & 54 & & & - & 2.10 & & & - & 2.00 \\
\hline Group 7 & 76 & & & - & 2.40 & & & - & 2.70 \\
\hline & 77 & & & - & 2.40 & & & - & 3.30 \\
\hline & 78 & & & - & 2.70 & & & - & 2.70 \\
\hline & 79 & & & - & 2.40 & & & - & 3.00 \\
\hline & Mean & & & - & $2.45 / 2.4$ & & & - & $2.62 / 2.6$ \\
\hline & SE & & & - & 0.07 & & & - & 0.16 \\
\hline
\end{tabular}

- = negative. Titres $\log _{10} \geq 1.2$ are considered positive. ${ }^{a} \mathrm{ET}=$ Ear Tag number. ${ }^{\mathrm{b}} \mathrm{dpc}=$ day post challenge. 
All the sheep were negative for antibodies to FMDV NSP at the time of vaccination and challenge (Supplementary table 7). For animals in phase 1, only two of the four nonvaccinated animals and five of 18 vaccinated animals were positive at $6 \mathrm{dpc}$. For animals euthanized at $35 \mathrm{dpc}$, all four non-vaccinated animals and 18 of 20 vaccinated were seropositive at the termination of the study (Supplementary table 7). There was no association between clinical protection and absence of antibodies against FMDV NSP.

\subsection{Comparison of the data between the different treatment groups}

The effect of vaccination on the excretion of virus in nasal secretions and presence of virus in serum was determined using a multivariable model (Table 3). Groups 1-3 did not differ significantly with the unvaccinated group $(P>0.05)$ while a highly significant difference was observed between Groups 4-6 and the other vaccine groups 1-3 and the unvaccinated controls $(P<0.001)$.

Table 3. Multivariable model results evaluating the effect of treatment group on the quantity of virus recovered from serum and nasal swabs.

\section{Variable Estimate $\left(95 \% \mathrm{Cl}^{\mathrm{a}}\right) \quad \mathrm{t}$ statistic $\mathrm{P}$ value}

Experimental group $<0.001$

$\begin{array}{llll}\text { Group } 1(0.25 \mathrm{ml}, 7 \mathrm{dpv}) & -0.330(-0.871,0.212) & -1.197 & 0.232 \\ \text { Group } 2(0.50 \mathrm{ml}, 7 \mathrm{dpv}) & -0.262(-0.777,0.254) & -0.999 & 0.318 \\ \text { Group } 3(1 \mathrm{ml}, 7 \mathrm{dpv}) & -0.285(-0.812,0.242) & -1.065 & 0.287 \\ \text { Group } 4(2 \mathrm{ml}, 7 \mathrm{dpv}) & -0.725(-1.074,-0.375)-4.082 & <0.001 \\ \text { Group } 5(1 \mathrm{ml}, 14 \mathrm{dpv}) & -0.799(-1.151,-0.447)-4.470 & <0.001 \\ \text { Group } 6(2 \mathrm{ml}, 14 \mathrm{dpv}) & -0.777(-1.127,-0.428)-4.377 & <0.001 \\ \text { Group } 7 \text { (unvaccinated) } & \text { Referent } & \end{array}$

Phase

Phase $1 \quad 0.305(-0.192,0.802) \quad 1.207 \quad 0.229$

Phase 2 Referent

Specimen type

Serum $\quad-1.606(-1.790,-1.421)-17.11<0.001$

Nasal swab Referent

$\mathrm{dpv}=$ days post vaccination

${ }^{\mathrm{a}} \mathrm{Cl}=$ confidence interval; Model estimates for the variables associated with days post-inoculation are not presented in the table.

\section{Discussion}

Vaccination against FMD during an outbreak is an additional measure that can be used to successfully control an outbreak in non-endemic countries. Although vaccines can offer clinical protection against the disease, they are less effective in preventing infection, virus excretion and sometimes, establishment of persistent infection (Cox et al., 2006; Golde et al., 2005; Muthukrishnan et al., 2012; Park et al., 2014; Stenfeldt et al., 2016a). However, several studies have shown that vaccination results in reduction of virus excretion and 
clinical signs when compared to unvaccinated animals (Stenfeldt et al., 2016a; Barnett et al., 2004). Although small ruminants like sheep and goats play an important role in FMD epidemiology and could become infected and transmit the disease, in many regions they are vaccinated only in the face of an outbreak and are not included in routine vaccination programs and campaigns (Patil et al 2002a,b). Some FMD free countries are undecided on whether or not to include extensive sheep farms during emergency vaccination.

There is little scientific evidence to support the use of half a cattle dose in small ruminants. For most emergency vaccination campaigns in previously free countries, a vaccine with $>6$ $\mathrm{PD}_{50}$ dose will be used and the recommended $1 \mathrm{ml}$ dose for sheep (Doel, 2003) would deliver a payload of at least $>3 \mathrm{PD}_{50}$ per dose depending on the antigen payload in the commercial vaccines, which could be $\geq 32 \mathrm{PD}_{50}$ (Brehm et al., 2008). Earlier studies have shown that a minimum antigen payload is required for protective responses in sheep but that it would not result in sterile immunity or absence of persistently infected animals (Muthukrishnan et al., 2012). However, the current practice of using one-half of the cattle dose of high potency vaccine is sufficient to induce protective immune responses in sheep and goats without the development of persistent infection (Muthukrishnan et al., 2010b). Therefore, where commercial formulations are used that guarantee an antigen payload $>6$ $\mathrm{PD}_{50}$, half the cattle dose would most likely be adequate to provide sterile immunity and prevent the development of persistently infected animals.

In this study, we tested this hypothesis with heterologous challenge where sheep received different doses of the vaccine $(2 x, 1 \times, 1 / 2 x$ and $1 / 4 x)$ and were challenged early post vaccination. Based on the limited number of animals and using the $C B$ challenge, sheep that received the recommended dose of vaccine $(1 x)$ were not protected against clinical disease at $7 \mathrm{dpv}$ but groups that received $2 \times$ dose showed partial protection. When challenge was done at 14 pdv partial protection was observed in groups receiving $1 \times$ or $2 \times$ vaccine dose.

Cox et al. (1999) have shown that in the event of airborne or contact challenge, sheep remain clinically protected as early as $4 \mathrm{dpv}$ with emergency vaccines. However, in this study, CB inoculation was the route of challenge using a relatively high challenge dose which could have delivered a more severe challenge, leading to a different result.

At $7 \mathrm{dpv}$, sheep vaccinated with $1 \times$ vaccine did not have detectable antibody titres but by 14 $\mathrm{dpv}, 6$ out of 7 sheep that had received $1 \times$ vaccine dose had antibody titres measuring $\geq 1.2 \log _{10}$. The clinical scores between these groups were significantly different $(P<0.05)$. Three of the seven sheep that received $2 \times$ vaccine had antibody titres of $\geq 1.2 \log _{10}$ at $7 \mathrm{dpv}$, while by $14 \mathrm{dpv}$ all seven sheep had titres. The clinical scores were not significantly different between these groups ( 5 and 6$)(P>0.05)$ but were significantly different from groups 1 to 4 $(P<0.05)$. It is known that protection in sheep is associated in part with induction of serum antibody responses, but that some sheep are protected despite low antibody titres (Cox et al., 1999). Our results indicated that the recommended dose of $1 \mathrm{ml}$ will be sufficient to offer clinical protection at least 14 days post vaccination with improved protection, especially at early time points, if the normal cattle $2 \mathrm{ml}$ dose is used. However, this will increase the cost of vaccinating sheep and decrease the number of doses available for other species. 
Barnett et al. (2004) reported that high potency emergency vaccines not only offered clinical protection but also reduced virus excretion and prevented the development of persistently infect animals, the co-called "carrier animals" $21 \mathrm{dpv}$ in sheep. In contrast, almost all the animals in phase 2 that were studied until $35 \mathrm{dpc}$ developed antibodies to NSP, indicating that vaccination did not completely prevent virus replication and that even the clinically protected animals did not develop sterile immunity (Supplementary table 7). This could be as a result of the early challenge time points and the direct inoculation route. Earlier studies have shown evidence for persistent infection in sheep and goats with significantly lower numbers of vaccinated and infected sheep compared to unvaccinated and infected animals (Muthukrishnan et al., 2010a; b, 2011, 2012, Orsel et al., 2007). In all these studies the challenge routes were different from each other and challenge occurred at $21 \mathrm{dpv}$. In the present study, using $28 \mathrm{dpv}$ as defining persistent infection, one of the seven sheep in each group that received $2 \times$ vaccine became 'carriers', compared to two of six sheep in group 5 that received $1 \times$ vaccine. Although the numbers of animals per group are low, it seems that the $2 \times$ vaccine was more effective at preventing persistent infection at early time points post vaccination (Fig. 3).

It is likely that many of the sera and swab samples during the incubation and clinical phases of infection of the non-protected animals contained infectious FMDV. However, it was not possible to determine the extent to which the lower levels of FMDV RNA detected in the samples correlated with isolation of infectious virus. This is because the relationship between RNA quantity and infectious virus titre is highly variable and dependent upon sample type, virus strain, immunological status of the animal, and cells used for isolation. For probang samples, six samples were PCR-positive, but VI negative, while five samples were positive only for live virus (Fig. 3). Neutralising antibodies in the mucosa following subclinical infection can interfere with virus isolation on cell culture (Burrows, 1966), but the TTE treatment of the probang samples likely facilitated isolation while it is possible that inhibitors could affect the PCR reactions. Although detection of FMDV RNA may be useful for diagnostic purposes to determine whether or not an animal has had contact with virus, RNA copy number alone is not sufficient as an indicator for determining the risk for disease transmission (Burrows, 1966). Only direct transmission studies would definitively demonstrate the biological significance of a reduction in virus load in vaccinated sheep.

This preliminary study indicated that vaccinating sheep with half the prescribed cattle dose $(1 \mathrm{ml})$ would offer only partial protection when challenged with a heterologous strain at early time points and would not prevent persistent infection. In contrast, the full dose $(2 \mathrm{ml})$ may offer better clinical protection and could reduce the risk of persistent infection developing in sheep. It would also be of interest to compare the two different vaccine doses with virus challenge at $21 \mathrm{dpv}$, when the immune response has matured. Studies with a serotype A vaccine against a variant of SEA genotype A virus, using an intra nasal challenge route in sheep, have shown that vaccination not only offered clinical protection but also prevented the development of persistently infected sheep (Horsington et al., 2015). It is therefore possible that in addition to the challenge route, the virus strain could also impact on development of persistent infection. 


\section{Acknowledgments}

Funding was provided in part by the livestock industries in Australia through Animal Health Australia (AHA). The relevant industry bodies are the Cattle Council of Australia, Australian Dairy Farmers, Australian Lot Feeders Association, Wool Producers Australia, Sheepmeat Council of Australia, Australian Pork Limited and the Goat Industry Council of Australia. The AHA funds are matched through the Meat and Livestock Australia Donor Company by the Australian Government under MLA Project P.PSH 0652. This work was also supported in part by USDA, Agricultural Research Service (ARS) (CRIS 1940-32000-057-00D). CS was recipient of a PIADC Research Participation Program fellowship administered by Oak Ridge Institute for Science and Education (ORISE) through an interagency agreement with the US Department of Energy. We also acknowledge the technical support provided by Mr Ethan J. Hartwig and Mr George R. Smoliga.

\section{References}

Arzt, J., Pacheco, J.M., Rodriguez, L.L., 2010. The early pathogenesis of foot-and-mouth disease in cattle after aerosol inoculation: identification of the nasopharynx as the primary site of infection. Vet. Pathol. 47, 1048-1063.

AUSVETPLAN, https://www.animalhealthaustralia.com.au/what-we-do/emergencyanimaldisease/ausvetplan/.

Barnett, P.V., Keel, P., Reid, S., Armstrong, R.M., Statham, R.J., Voyce, C., Aggarwal, N., Cox, S.J., 2004. Evidence that high potency foot-and-mouth disease vaccine inhibits local virus replication and prevents the "carrier" state in sheep. Vaccine 22, 1221-1232.

Brehm, K.E., Kumar, N., Thulke, H.-H., Haas, B., 2008. High potency vaccines induce protection against heterologous challenge with foot and mouth disease virus. Vaccine 26, 1681-1687.

Burrows, R., 1966. Studies on the carrier state of cattle exposed to foot-and-mouth disease virus. J. Hyg. (Lond) 64 (1), 81-90.

Cox, S.J., Barnett, P.V., Dani, P., Salt, J.S., 1999. Emergency vaccination of sheep against foot-andmouth disease: protection against disease and reduction in contact transmission. Vaccine 17, 18581868.

Cox, S.J., Aggarwal, N., Statham, R.J., Barnett, P.V., 2003. Longevity of antibody and cytokine responses following vaccination with high potency emergency FMD vaccines. Vaccine 21 (13e14), 1336-1347.

Cox, S.J., Voyce, C., Parida, S., Reid, S.M., Hamblin, P.A., Hutchings, G., Paton, D.J., Barnett, P.V., 2006. Effect of emergency FMD vaccine antigen payload on protection, sub-clinical infection and persistence following direct contact challenge of cattle. Vaccine 24, 3184-3190.

Doel, T.R., 2003. FMD vaccines. Virus Res. 91, 81-99.

Doel, T.R., Williams, L., Barnett, P.V., 1994. Emergency vaccination against foot-and-mouth disease: rate of development of immunity and its implications for the carrier state. Vaccine 12, 592600. 
EU Council Directive, 2003/85/EC. Community measures for the control of foot-and-mouth disease repealing Directive 85/511/EEC and Decisions 89/531/EEC and 91/665/EEC and amending Directive 92/46/EEC (Text with EEA relevance.). Off. J. L 306, 22/11/2003 P. 0001-0087.

FAO Statistical Year Book, 2013. http://www.fao.org/docrep/018/i3107e/i3107e00.htm.

Ferguson, N.M., Donnelly, C.A., Anderson, R.M., 2001. The foot-and-mouth epidemic in Great Britain: pattern of spread and impact of interventions. Science 292, 1155-1160.

Gibbens, J.C., Wilesmith, J.W., 2002. Temporal and geographical distribution of the cases of foot-and-mouth disease during the early weeks of the 2001 epidemic in Great Britain. Vet. Rec. 151, 407-412.

Gibson, C.F., Donaldson, A.I., Ferris, N.P., 1984. Response of sheep vaccinated with large doses of vaccine to challenge by airborne foot and mouth disease Virus. Vaccine 2, 157-161.

Golde, W.T., Pacheco, J.M., Duque, H., Doel, T., Penfold, B., Ferman, G.S., Gregg, D.R., Rodriguez, L.L., 2005. Vaccination against foot-and mouth disease virus confers complete clinical protection in 7 days and partial protection in 4 days: use in emergency outbreak response. Vaccine $23,5775-5782$.

Golding, S.M., Hedger, R.S., Talbot, P., 1976. Radial immuno-diffusion and serum neutralisation techniques for the assay of antibodies to swine vesicular disease. Res. Vet. Sci. 20, 142-147.

Haydon, D.T., Kao, R.R., Kitching, R.P., 2004. The UK foot-and-mouth disease outbreak e the aftermath. Nat. Rev. Microbiol. 2, 675-681.

Horsington, J., Zhang, Z., Bittner, H., Hole, K., Singanallur, N.B., Alexandersen, S., Vosloo, W., 2015. Early protection in sheep against intratypic heterologous challenge with serotype $O$ foot-and-mouth disease virus using high-potency, emergency vaccine. Vaccine 33, 422-429.

K€arber, G., 1931. Beitrag zur kollektiven Behandlung pharmakologischer Reihenversuche. Archives Exp. Pathol. Pharmacol. 162, 480-487.

LaRocco, M., Krug, P.W., Kramer, E., Ahmed, Z., Pacheco, J.M., Duque, H., Baxt, B., Rodriguez, L.L., 2013. A continuous bovine kidney cell line constitutively expressing bovine alphavbeta6 integrin has increased susceptibility to foot-and-mouth disease virus. J. Clin. Microbiol. 51 (6), 1714-1720.

Muthukrishnan, M., Singanallur, S.B., Lakshmi, M.N., Villuppanoor, S.A., 2010a. Effect of FMD vaccine antigen payload on protection, sub-clinical infection and persistence following needle challenge in sheep. Comp. Immunol. Microbiol. Inf. Dis. 33, e7-e13.

Muthukrishnan, M., Singanallur, N.B., Villuppanoor, S.A., 2010b. Protection against direct in-contact challenge following foot-and-mouth disease vaccination in sheep and goats: the effect on virus excretion and carrier status. Vet. Res. Comm. 34, 285-299.

Muthukrishnan, M., Singanallur, N.B., Ponsekaran, S., Dorairajan, T., Mangamoori, L.N., Villuppanoor, S.A., 2011. Immune response in goats to different payloads of FMDV monovalent vaccine: protection against virulent challenge and development of carrier status. Ind. J Microbiol. 51 (1), 88-93. 
Muthukrishnan, M., Singanallur, N.B., Ralla, K., Jagam, A., Kankipatti, M., Shanmugam, Y., Villuppanoor, S.A., 2012. Clinical protection., sub-clinical infection and persistence following vaccination with extinction payloads of $\mathrm{O} 1$ Manisa Foot-and-Mouth Disease monovalent vaccine and challenge in goats and comparison with sheep. Res. Vet. Sci. 93, 1050-1059.

Nishiura, H., Omori, R., 2010. An epidemiological analysis of the foot-and-mouth disease epidemic in Miqazaki, Japan. Transbound. Emerg. Dis. 57, 396-403.

OIE Terrestrial Manual, 2012. Foot and Mouth Disease, pp. 1-29 (Chapter 2).1.5.

Orsel, K., Dekker, A., Bouma, A., Stegeman, J.A., de Jong, M.C., 2007. Quantification of foot and mouth disease virus excretion and transmission within groups of lambs with and without vaccination. Vaccine 25, 2673-2679.

Pacheco, J.M., Mason, P.W., 2010. Evaluation of infectivity and transmission of different Asian footand-mouth disease viruses in swine. J. Vet. Sci. 11, 133-142.

Pacheco, J.M., Smoliga, G.R., O'Donnell, V., Brito, B.P., Stenfeldt, C., Rodriguez, L.L., Arzt, J., 2015. Persistent foot-and-mouth disease virus infection in the nasopharynx of cattle; tissue-specific distribution and local cytokine expression. Plos One 10 (5), e0125698.

Pacheco, J.M., Lee, K.-N., Esbaumer, M., Bishop, E.A., Hartwig, E.J., Pauszek, S.J., Smoliga, G.R., Kim, S.-M., Park, J.-H., Ko, Y.-J., Lee, H.-S., Tark, D., Cho, I.-S., Kim, B., Rodriguez, L.L., Arzt, J., 2016. Evaluation of infectivity, virulence and Transmission of FMDV field strains of serotypes $O$ and $A$ isolated in 2010 from outbreaks in Republic of Korea. PLOS ONE.

http://dx.doi.org/10.1371/journal.pone.0146445.

Parida, S., Fleming, L., Oh, Y., Mahapatra, M., Hamblin, P.A., Gloster, J., Paton, D.J., 2008. Emergency vaccination of sheep against foot-and-mouth disease: significance and detection of subsequent subclinical infection. Vaccine 26, 3469-3479.

Park, J.N., Lee, S.Y., Chu, J.Q., Lee, Y.J., Kim, R.H., Lee, K.N., Kim, S.M., Tark, D.S., Kim, B., 2014. Protection to homologous and heterologous challenge in pigs immunized with vaccine against footand-mouth disease type $O$ caused an epidemic in East Asia during 2010/2011. Vaccine 32, 18821889.

Patil, P.K., Bayry, J., Ramakrishna, C., Hugar, B., Misra, L.D., Natarajan, C., 2002a. Immune response of goats against foot-and-mouth disease quadrivalent vaccine: comparison of double oil emulsion and aluminium hydroxide gel vaccine in eliciting immunity. Vaccine 20, 2781-2789.

Patil, P.K., Bayry, J., Ramakrishna, C., Hugar, B., Misra, L.D., Prabhudas, K., Natarajan, C., 2002b. Immune responses of sheep to quadrivalent double emulsion foot-and-mouth disease vaccines: rate of development of immunity and variations among other ruminants. J. Clin. Microbiol. 40, 43674371.

Rasmussen, T.B., Uttenthal, A., de Stricker, K., Belak, S., Storgaard, T., 2003. Development of a novel quantitative real-time RT-PCR assay for the simultaneous detection of all serotypes of foot-andmouth disease virus. Arch. Virol. 148, 2005-2021. 
Singanallur, N.B., Villuppanoor, S.A., Muthukrishnan, M., Shanmugam, Y., Parida, S., Di Nardo, A., Horsington, J., Paton, D.J., 2011. Evaluation of cross-protection between 01 Manisa and 01 Campos in cattle vaccinated with foot-andmouth disease virus vaccine incorporating different payloads of inactivated 01 Manisa antigen. Vaccine 29 (10), 1906-1912.

Stenfeldt, C., Pacheco, J.M., Singanallur, N.B., deCarvalho-Ferreira, H.C., Vosloo, W., Rodriguez, L.L., Arzt, J., 2015. Clinical and virological dynamics of a serotype $O 2010$ South East Asia lineage footand-mouth disease virus in sheep using natural and simulated natural inoculation and exposure systems. Vet. Microbiol. 178 (1-e2), 50-60.

Stenfeldt, C., Eschbaumer, M., Rekant, S.I., Pacheco, J.M., Smoliga, G.R., Hartwig, E.J., Rodriguez, L.L., Arzt, J., 2016a. The foot-and-mouth disease carrier state divergence in cattle. J. Virol. 90, 6344-6364. http://dx.doi.org/10.1128/JVI.00388-16.

Stenfeldt, C., Pacheco, J.M., Smoliga, G.R., Bishop, E., Pauszek, S.J., Hartwig, E.J., Rodriguez, L.L., Arzt, J., 2016b. Detection of foot-and-mouth disease virus RNA and capsid protein in lymphoid tissues of convalescent pigs does not indicate existence of a carrier state. Transbound. Emerg. Dis. 63 (2), 152164.

Sutmoller, P., Olascoaga, R.C., 2002. The successful control and eradication of Foot and Mouth Disease epidemics in South America in 2001. In: Evidence for the Temporary Committee on Foot-andmouth Disease of the European Parliament Meeting, 2 September 2002, Strasbourg.

Valdazo-Gonzalez, B., Timina, A., Scherbakov, A., Abdul-Hamid, N.F., Knowles, N.J., King, D.P., 2013. Multiple introductions of serotype $O$ foot-and-mouth disease viruses into East Asia in 2010-2011. Vet. Res. 44, 76.

Yoon, H., Yoon, S.S., Kim, Y.J., Moon, O.K., Wee, S.H., Joo, Y.S., Kim, B., 2013. Epidemiology of the foot-and-mouth disease serotype $O$ epidemic of November 2010 to April 2011 in the Republic of Korea. Transbound. Emerg. Dis. 62, 252-263. 
Supplementary table 1. Detailed clinical score per animal.

\begin{tabular}{|c|c|c|c|c|c|c|c|c|}
\hline & & \multirow{2}{*}{$\mathbf{E} \mathbf{T}^{(1)}$} & \multicolumn{6}{|c|}{ Days post challenge } \\
\hline & & & $\mathbf{0}$ & 2 & 4 & 6 & 8 & 10 \\
\hline \multirow{5}{*}{$\begin{array}{l}\overrightarrow{0} \\
\stackrel{0}{0} \\
\stackrel{0}{0}\end{array}$} & $\frac{\sqrt{d}}{7}$ & 45 & 0 & 1 & 10 & 12 & & \\
\hline & $\frac{\partial}{2}$ & 46 & 0 & 0 & 4 & 7 & & \\
\hline & $r$ & 47 & 0 & 2 & 7 & 9 & & \\
\hline & $\underset{x}{x}$ & 49 & 0 & 1 & 11 & 11 & & \\
\hline & $\stackrel{ \pm}{=}$ & 50 & 0 & 1 & 3 & 4 & & \\
\hline \multirow{7}{*}{ 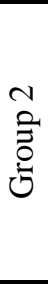 } & & 37 & 0 & 2 & 10 & 12 & & \\
\hline & & 38 & 0 & 0 & 0 & 0 & & \\
\hline & fr & 39 & 0 & 1 & 6 & 9 & & \\
\hline & 5 & 40 & 0 & 1 & 3 & 4 & & \\
\hline & $\underset{d}{x}$ & 41 & 0 & 2 & 8 & 10 & & \\
\hline & & 42 & 0 & 1 & 7 & 10 & & \\
\hline & & 43 & 0 & 3 & 9 & 10 & & \\
\hline \multirow{6}{*}{ 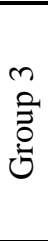 } & & 31 & 0 & 0 & 4 & 4 & & \\
\hline & $\vec{a}$ & 32 & 0 & 1 & 6 & 6 & & \\
\hline & ? & 33 & 0 & 0 & 4 & 6 & & \\
\hline & $\sqrt{3}$ & 34 & 0 & 0 & 4 & 11 & & \\
\hline & & 35 & 0 & 1 & 6 & 10 & & \\
\hline & & 36 & 0 & 1 & 4 & 13 & & \\
\hline \multirow{7}{*}{ 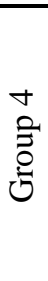 } & & 69 & 0 & 0 & 2 & 5 & 5 & 5 \\
\hline & & 70 & 0 & 0 & 0 & 0 & 0 & 0 \\
\hline & 름 & 71 & 0 & 0 & 0 & 0 & 0 & 0 \\
\hline & $r$ & 72 & 0 & 0 & 0 & 0 & 0 & 0 \\
\hline & $\dot{x}$ & 73 & 0 & 0 & 0 & 2 & 2 & 2 \\
\hline & & 74 & 0 & 0 & 4 & 5 & 5 & 5 \\
\hline & & 75 & 0 & 0 & 4 & 5 & 5 & 5 \\
\hline \multirow{7}{*}{ 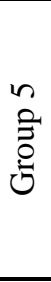 } & & 55 & 0 & 0 & 0 & 0 & 0 & 0 \\
\hline & & 56 & 0 & 0 & 0 & 0 & 0 & 0 \\
\hline & z & 57 & 0 & 0 & 1 & 2 & 4 & 4 \\
\hline & \pm & 58 & 0 & 0 & 0 & 0 & 0 & 0 \\
\hline & $\dot{x}$ & 59 & 0 & 0 & 1 & 4 & 4 & 4 \\
\hline & & 60 & 0 & 1 & 4 & 5 & 5 & 5 \\
\hline & & 61 & 0 & 0 & 0 & 0 & 0 & 0 \\
\hline \multirow{7}{*}{ 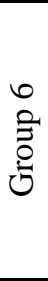 } & & 62 & 0 & 0 & 0 & 0 & 0 & 0 \\
\hline & & 63 & 0 & 0 & 0 & 0 & 0 & 0 \\
\hline & $\frac{\partial}{7}$ & 64 & 0 & 0 & 0 & 0 & 0 & 0 \\
\hline & \pm & 65 & 0 & 0 & 2 & 2 & 2 & 2 \\
\hline & $x$ & 66 & 0 & 0 & 0 & 0 & 0 & 0 \\
\hline & $\therefore$ & 67 & 0 & 0 & 4 & 7 & 7 & 7 \\
\hline & & 68 & 0 & 0 & 2 & 2 & 2 & 2 \\
\hline \multirow{8}{*}{ 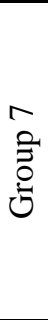 } & & 51 & 0 & 1 & 5 & 6 & & \\
\hline & & 52 & 0 & 6 & 12 & 12 & & \\
\hline & & 53 & 0 & 5 & 11 & 11 & & \\
\hline & $\stackrel{0}{:}$ & 54 & 0 & 1 & 7 & 8 & & \\
\hline & Z & 76 & 0 & 4 & 8 & 9 & 10 & 10 \\
\hline & & 77 & 0 & 3 & 9 & 9 & 9 & 9 \\
\hline & & 78 & 0 & 3 & 14 & 14 & 14 & 14 \\
\hline & & 79 & 0 & 9 & 13 & 15 & 15 & 15 \\
\hline
\end{tabular}

${ }^{(1)} \mathrm{ET}=$ Ear Tag Number; ${ }^{(2)} \mathrm{dpv}=$ day post vaccination

$1 / 4 \mathrm{X}=$ One fourth dose $; 1 / 2 \mathrm{X}=$ Half dose; $1 \mathrm{X}=$ Full dose; $2 \mathrm{X}=$ Two times the dose 
Supplementary table 2. Median (range) clinical score

\begin{tabular}{|c|c|c|c|c|c|c|c|c|}
\hline & Phase 1 & & & Phase 2 & & & & \\
\hline \multirow[b]{2}{*}{ Day $\mathbf{P C}^{(1)}$} & Group 1 & Group 2 & Group 3 & Group 4 & Group 5 & Group 6 & Group 7 & \multirow[b]{2}{*}{ P value $\dagger$} \\
\hline & $\begin{array}{l}0.25 \mathrm{ml}, 7 \\
\mathrm{dpv}^{(2)}\end{array}$ & $0.50 \mathrm{ml}, 7 \mathrm{dpv}$ & 1ml, $7 \mathrm{dpv}$ & $2 \mathrm{ml}, 7 \mathrm{dpv}$ & $1 \mathrm{ml}, 14 \mathrm{dpv}$ & $2 \mathrm{ml}, 14 \mathrm{dpv}$ & Unvaccinated & \\
\hline 2 & $1^{\mathrm{a}, \mathrm{b}}(0,2)$ & $1^{\mathrm{a}, \mathrm{b}}(0,3)$ & $0.5^{\mathrm{a}, \mathrm{b}}(0,1)$ & $0^{\mathrm{a}}(0,0)$ & $0^{\mathrm{a}}(0,1)$ & $0^{\mathrm{a}}(0,0)$ & $3.5^{\mathrm{b}}(1,9)$ & $<0.001$ \\
\hline 4 & $7^{\mathrm{a}, \mathrm{b}}(3,11)$ & $7^{\mathrm{a}, \mathrm{b}}(0,10)$ & $4^{\mathrm{a}, \mathrm{b}}(4,6)$ & $0^{\mathrm{a}}(0,4)$ & $0^{\mathrm{a}}(0,4)$ & $0^{\mathrm{a}}(0,4)$ & $10^{\mathrm{b}}(5,14)$ & $<0.001$ \\
\hline 6 & $9^{\mathrm{a}, \mathrm{b}}(4,12)$ & $10^{\mathrm{a}, \mathrm{b}}(0,12)$ & $8^{\mathrm{a}, \mathrm{b}}(4,13)$ & $2^{a}(0,5)$ & $0^{\mathrm{a}}(0,5)$ & $0^{\mathrm{a}}(0,7)$ & $10^{\mathrm{b}}(6,15)$ & $<0.001$ \\
\hline 8 & $\mathrm{ND}^{(3)}$ & ND & ND & $2^{a}(0,5)$ & $0^{\mathrm{a}}(0,5)$ & $0^{\mathrm{a}}(0,7)$ & $12^{\mathrm{a}}(9,15)$ & 0.011 \\
\hline 10 & ND & ND & ND & $2^{a}(0,5)$ & $0^{\mathrm{a}}(0,5)$ & $0^{\mathrm{a}}(0,7)$ & $12^{\mathrm{a}}(9,15)$ & 0.011 \\
\hline Overall & $4^{\mathrm{a}, \mathrm{b}}(0,12)$ & $4^{\mathrm{a}, \mathrm{b}}(0,12)$ & $4^{\mathrm{a}, \mathrm{b}}(0,13)$ & $0^{\mathrm{a}}(0,5)$ & $0^{\mathrm{a}}(0,5)$ & $0^{\mathrm{a}}(0,7)$ & $9^{b}(1,15)$ & $0.013 t$ \\
\hline
\end{tabular}

${ }^{(1)} \mathrm{PC}=$ Post-challenge; ${ }^{(2)} \mathrm{dpv}=$ day post vaccination; ${ }^{(3)} \mathrm{ND}=$ not done (animals euthanized)

$\dagger$ Based on Kruskal-Wallis for a difference among the 7 treatment groups. Medians without superscripts in common are significantly different based on pairwise Mann-Whitney $\mathrm{U}$ tests after Bonferroni correction of $\mathrm{P}$ values.

$\ddagger$ Based on mixed-effects linear regression on ranked transformed values for all days. Medians without superscripts in common are significantly different based on model results after Bonferroni correction of $\mathrm{P}$ values. 
Supplementary table 3. Median (range) serum PCR results $\left(\log _{10}\right)$

\begin{tabular}{|c|c|c|c|c|c|c|c|c|}
\hline \multirow[b]{2}{*}{ Day PC ${ }^{(1)}$} & \multicolumn{3}{|l|}{ Phase 1} & \multicolumn{3}{|l|}{ Phase 2} & \multirow[b]{2}{*}{$\begin{array}{l}\text { Group } 7 \\
\text { Unvaccinated }\end{array}$} & \multirow[b]{2}{*}{$P$ value $\dagger$} \\
\hline & $\begin{array}{l}\text { Group } 1 \\
0.25 \mathrm{ml}, 7 \mathrm{dpv}^{(2)}\end{array}$ & $\begin{array}{l}\text { Group } 2 \\
0.50 \mathrm{ml}, 7 \mathrm{dpv}\end{array}$ & $\begin{array}{l}\text { Group } 3 \\
\text { 1ml, } 7 \text { dpv }\end{array}$ & $\begin{array}{l}\text { Group } 4 \\
2 \mathrm{ml}, 7 \mathrm{dpv}\end{array}$ & $\begin{array}{l}\text { Group } 5 \\
\text { 1ml, } 14 \text { dpv }\end{array}$ & $\begin{array}{l}\text { Group } 6 \\
2 \mathrm{ml}, 14 \mathrm{dpv}\end{array}$ & & \\
\hline 1 & $6.96^{\mathrm{a}, \mathrm{b}}(<2.1,7.13)$ & $6.57^{\mathrm{a}}(<2.1,7.58)$ & $4.91^{\mathrm{a}, \mathrm{b}}(<2.1,6.80)$ & $<2.1^{\mathrm{a}, \mathrm{b}}(<2.1,3.67)$ & $<2.1^{\mathrm{a}, \mathrm{b}}(<2.1,5.11)$ & $\mathrm{NGD}^{\mathrm{b}}$ & $4.05(<2.1,8.54)$ & 0.002 \\
\hline 2 & $\mathrm{NGD}^{(3)}$ & NGD & NGD & $<2.1(<2.1,5.53)$ & $<2.1(<2.1,4.41)$ & $<2.1(<2.1,4.13)$ & $4.90(<2.1,9.08)$ & 0.065 \\
\hline 3 & $<2.1^{\mathrm{a}, \mathrm{b}}(<2.1,5.11)$ & $\mathrm{NGD}^{\mathrm{a}}$ & $<2.1^{\mathrm{a}, \mathrm{b}}(<2.1,4.90)$ & $<2.1^{\mathrm{a}, \mathrm{b}}(<2.1,5.00)$ & $\mathrm{NGD}^{\mathrm{a}}$ & $<2.1^{\mathrm{a}, \mathrm{b}}(<2.1,4.39)$ & $4.46^{\mathrm{b}}(<2.1,6.41)$ & 0.018 \\
\hline 4 & NGD & NGD & $<2.1(<2.1,3.87)$ & $<2.1(<2.1,2.66)$ & $<2.1(<2.1,4.15)$ & NGD & NGD & 0.369 \\
\hline 5 & NGD & NGD & NGD & NGD & NGD & NGD & $<2.1(<2.1,4.09)$ & 0.56 \\
\hline 6 & NGD & NGD & $<2.1(<2.1,4.45)$ & NGD & NGD & $<2.1(<2.1,4.20)$ & $<2.1(<2.1,4.02)$ & 0.456 \\
\hline 14 & $\mathrm{ND}^{(4)}$ & ND & ND & NGD & NGD & NGD & NGD & 1 \\
\hline 21 & ND & ND & ND & NGD & NGD & NGD & NGD & 1 \\
\hline 28 & ND & ND & ND & NGD & NGD & NGD & NGD & 1 \\
\hline 35 & $\mathrm{ND}$ & ND & ND & NGD & NGD & NGD & NGD & 1 \\
\hline Overall & $<2.1^{\mathrm{a}, \mathrm{b}}(<2.1,7.13)$ & $<2.1^{\mathrm{a}, \mathrm{b}}(<2.1,7.58)$ & $<2.1^{\mathrm{a}, \mathrm{b}}(<2.1,6.8)$ & $<2.1^{\mathrm{a}}(<2.1,5.53)$ & $<2.1^{\mathrm{a}}(<2.1,5.11)$ & $<2.1^{\mathrm{a}}(<2.1,4.39)$ & $<2.1^{\mathrm{b}}(<2.1,9.08)$ & $<0.001 \ddagger$ \\
\hline
\end{tabular}

${ }^{(1)} \mathrm{PC}=$ Post-challenge; ${ }^{(2)} \mathrm{dpv}=$ day post vaccination; ${ }^{(3)} \mathrm{NGD}=$ no genome detected $;{ }^{(4)} \mathrm{ND}=$ not done (animals euthanized).

$\dagger$ Based on Kruskal-Wallis for a difference among the 7 treatment groups. Medians without superscripts in common are significantly different based on pairwise Mann-Whitney $\mathrm{U}$ tests after Bonferroni correction of $\mathrm{P}$ values.

$\$$ Based on mixed-effects linear regression on values for all days. Medians without superscripts in common are significantly different based on model results after Bonferroni correction of $\mathrm{P}$ values. 
Supplementary table 4. Median (range) nasal swab PCR results $\left(\log _{10}\right)$

\begin{tabular}{|c|c|c|c|c|c|c|c|c|}
\hline \multirow[b]{2}{*}{ Day $P^{(1)}$} & \multicolumn{3}{|l|}{ Phase 1} & \multicolumn{3}{|l|}{ Phase 2 } & \multirow[b]{2}{*}{$\begin{array}{l}\text { Group } 7 \\
\text { Unvaccinated }\end{array}$} & \multirow[b]{2}{*}{$P$ value $\dagger$} \\
\hline & $\begin{array}{l}\text { Group } 1 \\
0.25 \mathrm{ml}, 7 \mathrm{dpv}^{(2)}\end{array}$ & $\begin{array}{l}\text { Group } 2 \\
0.50 \mathrm{ml}, 7 \mathrm{dpv}\end{array}$ & $\begin{array}{l}\text { Group } 3 \\
1 \mathrm{ml}, 7 \mathrm{dpv}\end{array}$ & $\begin{array}{l}\text { Group } 4 \\
2 \mathrm{ml}, 7 \mathrm{dpv}\end{array}$ & $\begin{array}{l}\text { Group } 5 \\
\text { 1ml, } 14 \text { dpv }\end{array}$ & $\begin{array}{l}\text { Group } 6 \\
2 \mathrm{ml}, 14 \mathrm{dpv}\end{array}$ & & \\
\hline 1 & $6.73^{\mathrm{a}}(<3.0,8.45)$ & $6.17^{\mathrm{a}}(<3.0,8.77)$ & $5.40^{\mathrm{a}}(<3.0,6.68)$ & $4.89^{\mathrm{a}}(<3.0,5.24)$ & $<3.0^{\mathrm{a}}(<3.0,5.70)$ & $<3.0^{\mathrm{a}}(<3.0,5.09)$ & $7.17^{\mathrm{a}}(<3.0,8.20)$ & 0.004 \\
\hline 2 & $6.58^{\mathrm{a}, \mathrm{b}}(<3.0,8.30)$ & $6.06^{\mathrm{a}, \mathrm{b}}(<3.0,8.16)$ & $6.99^{\mathrm{a}, \mathrm{b}}(<3.0,7.75)$ & $5.27^{\mathrm{a}, \mathrm{b}}(<3.0,6.29)$ & $5.37^{\mathrm{a}}(<3.0,5.59)$ & $5.47^{\mathrm{a}, \mathrm{b}}(4.85,6.23)$ & $8.03^{\mathrm{b}}(<3.0,9.73)$ & 0.034 \\
\hline 3 & $<3.0^{\mathrm{a}}(<3.0,5.44)$ & $<3.0^{\mathrm{a}}(<3.0,7.88)$ & $4.95^{\mathrm{a}, \mathrm{b}}(<3.0,5.72)$ & $5.21^{\mathrm{a}, \mathrm{b}}(<3.0,5.82)$ & $5.38^{\mathrm{a}, \mathrm{b}}(<3.0,6.53)$ & $5.49^{\mathrm{a}, \mathrm{b}}(<3.0,6.31)$ & $7.08^{\mathrm{b}}(5.09,8.49)$ & 0.004 \\
\hline 4 & $5.27^{\mathrm{a}}(<3.0,7.31)$ & $5.96^{\mathrm{a}}(4.72,7.15)$ & $5.26^{\mathrm{a}}(<3.0,6.73)$ & $5.03^{\mathrm{a}}(<3.0,5.75)$ & $5.06^{\mathrm{a}}(<3.0,5.98)$ & $4.99^{\mathrm{a}}(<3.0,5.72)$ & $6.38^{\mathrm{a}}(5.02,7.51)$ & 0.023 \\
\hline 5 & $5.14^{\mathrm{a}, \mathrm{b}}(4.81,6.00)$ & $5.83^{\mathrm{a}, \mathrm{b}}(<3.0,6.57)$ & $6.00^{\mathrm{a}}(<3.0,6.82)$ & $4.98^{\mathrm{a}, \mathrm{b}}(<3.0,5.19)$ & $<3.0^{\mathrm{a}, \mathrm{b}}(<3.0,5.56)$ & $<3.0^{\mathrm{b}}(<3.0,4.96)$ & $6.08^{\mathrm{a}, \mathrm{b}}(<3.0,6.40)$ & 0.008 \\
\hline 6 & $4.32(<3.0,5.87)$ & $<3.0(<3.0,6.03)$ & $4.91(<3.0,5.87)$ & $<3.0(<3.0,5.33)$ & $<3.0(<3.0,5.15)$ & $<3.0(<3.0,5.13)$ & $5.14(<3.0,6.19)$ & 0.291 \\
\hline 14 & $\mathrm{ND}^{(3)}$ & ND & $\mathrm{ND}$ & $<3.0(<3.0,5.52)$ & $<3.0(<3.0,5.11)$ & $\mathrm{NGD}^{(4)}$ & $<3.0(<3.0,4.13)$ & 0.541 \\
\hline 21 & ND & ND & ND & NGD & $<3.0(<3.0,4.84)$ & NGD & NGD & 0.392 \\
\hline 28 & ND & ND & ND & NGD & NGD & $<3.0(<3.0,4.87)$ & NGD & 0.488 \\
\hline 35 & $\mathrm{ND}$ & $\mathrm{ND}$ & ND & NGD & NGD & NGD & NGD & 1 \\
\hline Overall & $5.30^{\mathrm{a}, \mathrm{b}}(<3.0,8.45)$ & $5.40^{\mathrm{a}, \mathrm{b}}(<3.0,8.77)$ & $5.39^{\mathrm{a}, \mathrm{b}}(<3.0,7.75)$ & $<3.0^{\mathrm{a}}(<3.0,6.29)$ & $<3.0^{\mathrm{a}}(<3.0,6.53)$ & $<3.0^{\mathrm{a}}(<3.0,6.31)$ & $4.77^{\mathrm{b}}(<3.0,9.73)$ & $0.001 \%$ \\
\hline
\end{tabular}

${ }^{(1)} \mathrm{PC}=$ Post-challenge. ${ }^{(2)} \mathrm{dpv}=$ day post vaccination; ${ }^{(3)} \mathrm{ND}=$ not done (animals euthanized). ${ }^{(4)} \mathrm{NGD}=$ no genome detected.

$\dagger$ Based on Kruskal-Wallis for a difference among the 7 treatment groups. Medians without superscripts in common are significantly different based on pairwise Mann-Whitney $\mathrm{U}$ tests after Bonferroni correction of $\mathrm{P}$ values.

$\$$ Based on mixed-effects linear regression on values for all days. Medians without superscripts in common are significantly different based on model results after Bonferroni correction of $\mathrm{P}$ values. 
Supplementary table 5. Median (range) probang PCR results $\left(\log _{10}\right)$

\begin{tabular}{|c|c|c|c|c|c|}
\hline Day $P C^{(1)}$ & $\begin{array}{l}\text { Group } 4 \\
2 \mathrm{ml}, 7 \mathbf{d p v}^{(2)} \\
\end{array}$ & $\begin{array}{l}\text { Group } 5 \\
\text { 1ml, } 14 \text { dpvpv } \\
\end{array}$ & $\begin{array}{l}\text { Group } 6 \\
2 \mathrm{ml}, 14 \mathrm{dpv} \\
\end{array}$ & $\begin{array}{l}\text { Group } 8 \\
\text { Unvaccinated } \\
\end{array}$ & P value* \\
\hline 14 & $<3.0^{\mathrm{a}}(<3.0,5.48)$ & $<3.0^{\mathrm{a}}(<3.0,4.77)$ & $\mathrm{NGD}^{\mathrm{a}}$ & $4.47^{\mathrm{a}}(<3.0,7.11)$ & 0.039 \\
\hline 17 & $<3.0(<3.0,5.92)$ & $<3.0(<3.0,5.25)$ & NGD & $5.76(<3.0,6.90)$ & 0.067 \\
\hline 21 & $<3.0^{\mathrm{a}}(<3.0,6.28)$ & $<3.0^{\mathrm{a}}(<3.0,5.31)$ & $\mathrm{NGD}^{\mathrm{a}}$ & $5.92^{\mathrm{a}}(<3.0,6.64)$ & 0.02 \\
\hline 24 & $<3.0^{\mathrm{a}}(<3.0,5.23)$ & $<3.0^{\mathrm{a}}(<3.0,5.18)$ & $\mathrm{NGD}^{\mathrm{a}}$ & $5.50^{\mathrm{a}}(<3.0,6.27)$ & 0.034 \\
\hline 28 & ${ }^{(3)} \mathrm{NGD}^{\mathrm{a}}$ & $<3.0^{\mathrm{a}, \mathrm{b}}(<3.0,5.65)$ & $\mathrm{NGD}^{\mathrm{a}}$ & $4.89^{\mathrm{b}}(<3.0,6.58)$ & 0.009 \\
\hline 31 & $<3.0^{\mathrm{a}, \mathrm{b}}(<3.0,4.84)$ & $\mathrm{NGD}^{\mathrm{a}}$ & $\mathrm{NGD}^{\mathrm{a}}$ & $5.12^{\mathrm{b}}(<3.0,6.29)$ & 0.007 \\
\hline 35 & NGD & NGD & NGD & NGD & 1 \\
\hline Overall & $<3.0^{\mathrm{a}}(<3.0,6.28)$ & $<3.0^{\mathrm{a}}(<3.0,5.65)$ & $\mathrm{NGD}^{\mathrm{a}}$ & $4.17^{\mathrm{b}}(<3.0,7.11)$ & $0.002 \dagger$ \\
\hline
\end{tabular}

${ }^{(1)} \mathrm{PC}=$ Post-challenge $;{ }^{(2)} \mathrm{dpv}=$ day post vaccination; ${ }^{(3)} \mathrm{NGD}=$ no genome detected. *Based on Kruskal-Wallis for a difference among the 7 treatment groups. Medians without superscripts in common are significantly different based on pairwise Mann-Whitney U tests after Bonferroni correction of $\mathrm{P}$ values.

$\uparrow$ Based on mixed-effects linear regression on values for all days. Medians without superscripts in common are significantly different based on model results after Bonferroni correction of $\mathrm{P}$ values. 
Supplementary table 6. Median (range) serological titres.

\begin{tabular}{|c|c|c|c|c|c|c|c|c|}
\hline & \multicolumn{3}{|l|}{ Phase 1 } & \multicolumn{3}{|l|}{ Phase 2} & \multirow[b]{2}{*}{$\begin{array}{l}\text { Group } 7 \\
\text { Unvaccinated }\end{array}$} & \multirow[b]{2}{*}{ P value $\dagger$} \\
\hline & $\begin{array}{l}\text { Group } 1 \\
0.25 \mathrm{ml}, 7 \mathrm{dpv}^{(1)} \\
\end{array}$ & $\begin{array}{l}\text { Group } 2 \\
\text { 0.50ml, } 7 \text { dpv }\end{array}$ & $\begin{array}{l}\text { Group } 3 \\
1 \mathrm{ml}, 7 \mathrm{dpv} \\
\end{array}$ & $\begin{array}{l}\text { Group } 4 \\
2 \mathrm{ml}, 7 \text { dpvpv } \\
\end{array}$ & $\begin{array}{l}\text { Group } 5 \\
1 \mathrm{ml}, 14 \text { dpv } \\
\end{array}$ & $\begin{array}{l}\text { Group } 6 \\
2 \mathrm{ml}, 14 \mathrm{dpv} \\
\end{array}$ & & \\
\hline \multicolumn{9}{|c|}{$\begin{array}{l}\mathrm{VNT}^{(2)}, \\
\text { homologous }\end{array}$} \\
\hline Day 0 & ${ }^{(3)} \mathrm{AN}^{\mathrm{a}}$ & $\mathrm{AN}^{\mathrm{a}}$ & $\mathrm{AN}^{\mathrm{a}}$ & $0.9^{\mathrm{a}, \mathrm{b}}(<0.9,1.2)$ & $1.2^{\mathrm{b}}(1.2,1.8)$ & $1.2^{\mathrm{b}}(<0.9,1.8)$ & $\mathrm{AN}^{\mathrm{a}}$ & $<0.001$ \\
\hline Day 6 & $2.1^{\mathrm{a}}(1.8,2.4)$ & $2.4^{\mathrm{a}}(1.8,2.7)$ & $2.1^{\mathrm{a}}(<0.9,2.4)$ & $3.0^{\mathrm{a}}(2.4,3.3)$ & $2.7^{\mathrm{a}}(2.4,3.0)$ & $3.0^{\mathrm{a}}(2.1,3.3)$ & $2.4^{\mathrm{a}}(2.1,2.7)$ & 0.009 \\
\hline \multicolumn{9}{|c|}{$\begin{array}{l}\text { VNT, } \\
\text { heterologous }\end{array}$} \\
\hline Day 0 & $\mathrm{AN}^{\mathrm{a}}$ & $\mathrm{AN}^{\mathrm{a}}$ & $\mathrm{AN}^{\mathrm{a}}$ & $0.9^{\mathrm{a}, \mathrm{b}}(<0.9,1.2)$ & $1.2^{\mathrm{b}}(<0.9,1.8)$ & $1.5^{\mathrm{b}}(1.2,2.1)$ & $\mathrm{AN}^{\mathrm{a}}$ & $<0.001$ \\
\hline Day 6 & $2.4^{\mathrm{a}, \mathrm{c}}(2.4,2.4)$ & $2.4^{\mathrm{a}}(2.1,2.4)$ & $2.4^{\mathrm{a}}(1.2,2.4)$ & $3.3^{\mathrm{b}}(3.0,3.3)$ & $2.7^{\mathrm{a}, \mathrm{b}}(2.4,3.0)$ & $3.0^{\mathrm{b}, \mathrm{c}}(2.4,3.6)$ & $2.6^{\mathrm{a}, \mathrm{b}}(2.0,3.3)$ & $<0.001$ \\
\hline \multicolumn{9}{|c|}{$\mathbf{N S P}^{(4)}$ ELISA } \\
\hline Day 0 & $16.2(2.9,33.6)$ & $26.2(12.4,39.2)$ & $20.5(10.9,28.9)$ & $19.8(17.8,37.7)$ & $14.7(11.8,23.9)$ & $23.4(10.7,39.2)$ & $26.3(7.9,32.8)$ & 0.56 \\
\hline Day 6 & $\begin{array}{l}40.9(28.8, \\
49.1)\end{array}$ & $51.0(36.2,68.0)$ & $47.3(34.4,60.7)$ & $\mathrm{ND}^{(5)}$ & ND & ND & $42(5.8,55.5)$ & 0.357 \\
\hline Day 35 & ND & ND & ND & $65.6(44.8,91.3)$ & $71.3(64.4,81.1)$ & $69.4(46.4,89.0)$ & $68.6(59.2,73.0)$ & 0.912 \\
\hline
\end{tabular}

${ }^{(1)} \mathrm{dpv}=$ day post vaccination; ${ }^{(2)} \mathrm{VNT}=$ virus neutralization test $;{ }^{(3)} \mathrm{AN}=$ all negative, no serological titres; ${ }^{(4)} \mathrm{NSP}=$ non-structural protein; ${ }^{(5)} \mathrm{ND}$ $=$ not done.

$\dagger$ Based on Kruskal-Wallis for a difference among treatment groups. Medians without superscripts in common are significantly different based on pairwise Mann-Whitney $\mathrm{U}$ tests after Bonferroni correction of $\mathrm{P}$ values. 
Supplementary table 7: Results of NSP serology in different vaccine groups post-challenge

\begin{tabular}{|c|c|c|c|c|}
\hline Groups & $\mathrm{ET}^{(1)}$ & $0 \mathrm{dpc} \mathrm{c}^{(2)}$ & $6 \mathrm{dpc}$ & $35 \mathrm{dpc}$ \\
\hline \multirow{7}{*}{$\begin{array}{l}\overrightarrow{0} \\
\stackrel{0}{0} \\
\stackrel{0}{0}\end{array}$} & 44 & $\mathrm{Neg}$ & ND & $\mathrm{NA}$ \\
\hline & 45 & $\mathrm{Neg}$ & Neg & NA \\
\hline & 46 & $\mathrm{Neg}$ & $\mathrm{Neg}$ & NA \\
\hline & 47 & $\mathrm{Neg}$ & $\mathrm{Neg}$ & NA \\
\hline & 48 & $\mathrm{Neg}$ & ND & NA \\
\hline & 49 & $\mathrm{Neg}$ & $\mathrm{Neg}$ & NA \\
\hline & 50 & $\mathrm{Neg}$ & $\mathrm{Neg}$ & NA \\
\hline \multirow{7}{*}{ 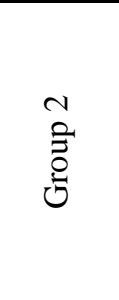 } & 37 & $\mathrm{Neg}$ & Pos & NA \\
\hline & 38 & $\mathrm{Neg}$ & Pos & NA \\
\hline & 39 & $\mathrm{Neg}$ & Neg & NA \\
\hline & 40 & $\mathrm{Neg}$ & $\mathrm{Neg}$ & NA \\
\hline & 41 & $\mathrm{Neg}$ & $\mathrm{Neg}$ & NA \\
\hline & 42 & $\mathrm{Neg}$ & Pos & NA \\
\hline & 43 & $\mathrm{Neg}$ & Pos & NA \\
\hline \multirow{7}{*}{ 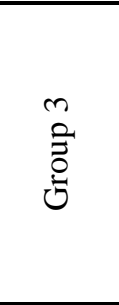 } & 30 & $\mathrm{Neg}$ & ND & NA \\
\hline & 31 & $\mathrm{Neg}$ & Neg & NA \\
\hline & 32 & $\mathrm{Neg}$ & $\mathrm{Neg}$ & NA \\
\hline & 33 & $\mathrm{Neg}$ & $\mathrm{Neg}$ & NA \\
\hline & 34 & $\mathrm{Neg}$ & $\mathrm{Neg}$ & NA \\
\hline & 35 & $\mathrm{Neg}$ & Pos & NA \\
\hline & 36 & $\mathrm{Neg}$ & $\mathrm{Neg}$ & NA \\
\hline \multirow{7}{*}{$\begin{array}{l}+ \\
\stackrel{\ominus}{\Xi} \\
\stackrel{0}{0}\end{array}$} & 69 & $\mathrm{Neg}$ & ND & Pos \\
\hline & 70 & $\mathrm{Neg}$ & ND & Pos \\
\hline & 71 & $\mathrm{Neg}$ & ND & $\mathrm{Neg}$ \\
\hline & 72 & $\mathrm{Neg}$ & ND & Pos \\
\hline & 73 & $\mathrm{Neg}$ & ND & Pos \\
\hline & 74 & $\mathrm{Neg}$ & ND & Pos \\
\hline & 75 & $\mathrm{Neg}$ & ND & Pos \\
\hline \multirow{7}{*}{ 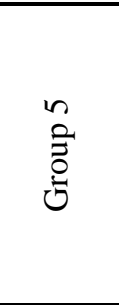 } & 55 & $\mathrm{Neg}$ & ND & Pos \\
\hline & 56 & $\mathrm{Neg}$ & ND & Pos \\
\hline & 57 & $\mathrm{Neg}$ & ND & Pos \\
\hline & 58 & $\mathrm{Neg}$ & ND & $\mathrm{Neg}$ \\
\hline & 59 & $\mathrm{Neg}$ & ND & Pos \\
\hline & 60 & $\mathrm{Neg}$ & ND & Pos \\
\hline & 61 & $\mathrm{Neg}$ & ND & Pos \\
\hline \multirow{7}{*}{$\begin{array}{l}0 \\
\stackrel{0}{Z} \\
0 \\
0\end{array}$} & 62 & $\mathrm{Neg}$ & ND & Pos \\
\hline & 63 & $\mathrm{Neg}$ & ND & Pos \\
\hline & 64 & $\mathrm{Neg}$ & ND & $\mathrm{Neg}$ \\
\hline & 65 & $\mathrm{Neg}$ & ND & Pos \\
\hline & 66 & $\mathrm{Neg}$ & ND & Pos \\
\hline & 67 & $\mathrm{Neg}$ & ND & Pos \\
\hline & 68 & $\mathrm{Neg}$ & ND & Pos \\
\hline \multirow{8}{*}{$\stackrel{\circ}{0}$} & 51 & $\mathrm{Neg}$ & $\mathrm{Neg}$ & NA \\
\hline & 52 & $\mathrm{Neg}$ & $\mathrm{Neg}$ & NA \\
\hline & 53 & $\mathrm{Neg}$ & Pos & NA \\
\hline & 54 & $\mathrm{Neg}$ & Pos & NA \\
\hline & 76 & $\mathrm{Neg}$ & ND & Pos \\
\hline & 77 & $\mathrm{Neg}$ & ND & Pos \\
\hline & 78 & $\mathrm{Neg}$ & ND & Pos \\
\hline & 79 & $\mathrm{Neg}$ & ND & Pos \\
\hline
\end{tabular}

